\title{
Effects of Multivitamins and Enzymes on Growth Performance and Hematological Parameters of Broilers at Meherpur in Bangladesh
}

\author{
Zannatul Ferdous ${ }^{1,}$ M Aktaruzzaman ${ }^{2}$, MM Rahman ${ }^{1}$ and MMR Howlader ${ }^{1 *}$ \\ ${ }^{1}$ Department of Physiology, Sylhet Agricultural University, Bangladesh \\ ${ }^{2}$ Department of Pharmacology and Toxicology, Bangladesh \\ Submission: December 22, 2017 ; Published: April 20, 2018 \\ *Corresponding author: MMR Howlader, Department of Physiology, Faculty of Veterinary, Animal and Biomedical Sciences, Sylhet Agricultural \\ University, Sylhet-3100, Bangladesh, Email: howlader.sau@gmail.com
}

\begin{abstract}
The experiment was conducted on broiler chicks to evaluate the effects of enzymes and multivitamin supplementation on body weight gain and hematological parameters (TEC, Hb content, PCV and ESR). A total of 200 day old broiler chicks were randomly selected and divided into four equal groups $(50 \times 4)$ as $\mathrm{T}_{0}, \mathrm{~T}_{1}, \mathrm{~T}_{2}$ and $\mathrm{T}_{3}$. Group $\mathrm{T} 0$ was considered as control, (fed only with commercial ration) and other groups $\mathrm{T}_{1}, \mathrm{~T}_{2}$ and $\mathrm{T}_{3}$ were treated at a dose rate of $0.5 \mathrm{~g}$ multivitamins per liter of drinking water, $1 \mathrm{~g}$ enzymes per liter of drinking water and $0.5 \mathrm{~g}$ multivitamins plus 1 g enzymes per liter of drinking water, respectively, from 0 to 28 days of experiment. It was observed that enzymes and vitamins supplementation significantly $(\mathrm{p}<0.01)$ increased body weight with better physical appearance. TEC, PCV and Hb content increased significantly $(\mathrm{p}<0.01)$ in the treated groups as compared to that of control group. ESR values decreased significantly $(p<0.01)$ in the treated groups from that of the control groups. Therefore, it may be concluded that enzymes and vitamins may be used with water to get best result in terms of body weight gain and blood profiles without any detrimental effects on broilers.

Keywords:Multivitamin and enzyme; Growth performance; Hematological parameters; Galactosidases; Xylanases; pectinases; raffinose; hemicelluloses; amylase; protease; $\beta$-glucanase; livestock; polysaccharides; Hemoglobin
\end{abstract}

\section{Introduction}

In Bangladesh, livestock contributes $2.73 \%$ of total GDP (Bangladesh Bureau of Statistics). About 15\% of her total population suffers from malnutrition due to deficiency of calorie and protein [1]. The availability of animal protein in the country is only $7.6 \mathrm{~g}$ [2], against the FAO recommendation of 28g. Poultry sub-sector is an important avenue to reduce the gap between demand and supply of animal protein.

Enzyme and multivitamin protect deficiency diseases and stimulate growth rate. Beside this, enzyme supplement along with multivitamin reduces mortality, keep birds healthy, increase feed intake, improve digestion and feed conversion rate. Most of the feed ingredients contain some anti-nutritional factors and indigestible part, which hinders feed utilization and bird's performance.

In commercial poultry farming feed cost is a major contributor as it covers $65-70 \%$ of farm expenses. In feed formulation grains have major share which contain non-starch polysaccharides (NSPs). These NSPs are not digestible by the endogenous enzymes of poultry. In order to make them available for digestion, certain enzymes are supplemented. Legume seeds also contain
NSP-like hemicelluloses, mannan, and raffinose. Chickens are unable to produce some enzymes, such as galactosidases; thus, corn- soybean-based diets without supplemented enzymes such as xylanases and pectinases might result in gas accumulation in the gut and diarrhea [3].

Supplementation of poultry diets with exogenous enzymes is one approach to help animals in hydrolysis of these oligosaccharides [4,5]. Enzyme supplementation is considered to break the bond among NSPs and reduce their anti-nutritional effect and results in improved nutritional value of feed materials $[6,7]$. The effect of exogenous enzyme may be variable as it is dependent on different factors like bird age, feed type and quality $[8,9]$.

Widely used enzymes in feed industry are - galactosidase, amlyase, $\beta$-glucanase, cellulase, protease, pectinase and xylanase that cleave the non-starch polysaccharides in cereals and vegetable meals. Protease breaks down proteins by proteolysis of the peptide bonds that link amino acids together in the polypeptide chain forming the protein. Proteases work best in acidic conditions except alkaline proteases. Its optimal activity is shown in alkaline $\mathrm{pH}[10]$. 
Based on the above mentioned perspective, the present research work was undertaken to fulfill the following research objectives:

a. To evaluate the effect of enzymes and multivitamins supplementation on growth performance in broilers.

b. To study the effect of enzymes and multivitamins supplementation on broiler in terms of hematological parameters (TEC, Hb, PCV and ESR).

\section{Materials and Methods}

The experiment was conducted under the department of physiology, Sylhet Agricultural University. The hematological test was performed at Upazila Veterinary Hospital, Gangni, Meherpur.

For this study a total of 200 day old chicks were purchased from C.P Company Ltd and randomly divided into four (4) equal groups $(50 \times 4)$ and numbered them as group $\mathrm{T}_{0}, \mathrm{~T}_{1}, \mathrm{~T}_{2}$ and $\mathrm{T}_{3}$. Group $\mathrm{T}_{0}$ was considered as control. Birds were housed into a well ventilated, proper atmosphere and hygienic condition. The broilers were feed with standard broiler starter and broiler finisher ration throughout the experimental period. Group $\mathrm{T}_{1}$ was treated with supplementation of $1 \mathrm{gm}$ enzymes/liter drinking water. Group $\mathrm{T}_{2}$ was treated with supplementation of $0.5 \mathrm{gm}$ vitamins/liter drinking water and Group $\mathrm{T}_{3}$ was treated with supplementation of $1 \mathrm{gm}$ enzymes plus $0.5 \mathrm{gm}$ vitamins/liter drinking water. Initial body weight of each bird was recorded just prior to segregation and kept them into pens. Fresh, clean and normal drinking water was made available for all times to the birds. Feeder and waterier were provided to the birds according to the recommendation of Panda et al. Each pen was $2.5 \mathrm{ft} \times 2 \mathrm{ft}$ and was allotted for 200 birds. Therefore, floor space provided for each bird was $1 \mathrm{fT}^{2}$. Fresh and dry rice husk was used as litter at a depth of about $4 \mathrm{~cm}$. As per head the old litter material was changed using new rice husk to prevent birds from fungal or coccidian attack. The birds were exposed to a continuous lighting of 12 hours a day. During night electric birds were used to provide necessary light. In order to maintain required temperature and humidity inside the pen all the windows of the farm were kept open during day and at night electric bulb were provided as a source of heat. Body weight was recorded at 7 days interval up to the end of the 28 days of experimental period and collection of blood sample for hematological study (TEC, Hb, PCV and ESR) by acid hematin method. For hematological test $5 \mathrm{ml}$ of blood was collected with anticoagulant in the sterile glass test tubes.

Table 1: Effect of vitamins and enzymes on body weight of broilers
After collection of data from the farm, verified to eliminate errors and inconsistencies. Then the data were tabulated into computer. The data generated from this study was entered in Microsoft excel worksheet, organized and processed for further analysis. All data were analyzed by One-way ANOVA using Minitab 17 Statistical Software. Finished test was further done for comparison of means.

\section{Results}

Body weight on 7 days of age (day 0 of experiment) was more or less similar. Highest body weight was recorded in group $\mathrm{T}_{3}$ and lowest in group $\mathrm{T}_{0}$. The recorded body weight was $125.24 \pm 2.04$ gm in group $T_{0}, 128.32$ gm in group $T_{1}, 130.35$ in group $\mathrm{T}_{2}$ and $132.25 \pm 3.39 \mathrm{gm}$ in group $\mathrm{T}_{3}$.

On 14 days of age ( $7^{\text {th }}$ day of experiment) it was observed that the body weight in control group $\mathrm{T}_{0}$ was $530.56 \pm 3.53 \mathrm{gm}$, in group $\mathrm{T}_{1}$ was $550.43 \pm 5 \mathrm{gm}$, in group $\mathrm{T}_{2}$ was $535.34 \pm 7.91 \mathrm{gm}$ and in group $\mathrm{T}_{3}$ was $563.21 \pm 8.60 \mathrm{gm}$. All the data were statistically significant $(\mathrm{p}<0.01)$. The highest and lowest body weight was observed as $563.21 \pm 8.60 \mathrm{gm}$ and $530.56 \pm 3.53 \mathrm{gm}$, respectively.

On 21 days of age ( $14^{\text {th }}$ day of experiment) the body weight in control group $\mathrm{T}_{0}$ was $901.24 \pm 13.45 \mathrm{gm}$ and in the treated groups were $955.54 \pm 8.43 \mathrm{gm}$ in group $\mathrm{T}_{1}, 949.37 \pm 16.58 \mathrm{gm}$ in group $\mathrm{T}_{2}$ and $1059.65 \pm 22.49 \mathrm{gm}$ in group $\mathrm{T}_{3}$. The increased rates were statistically significant $(\mathrm{p}<0.01)$. The highest body weight was recorded in treated group $\mathrm{T}_{3}$ and lowest in control group $\mathrm{T}_{0}$. But among the treated groups the lowest body weight was recorded in group $\mathrm{T}_{0}$. But among the treated groups the lowest body weight was recorded in group $\mathrm{T}_{2}$.

On 28 days of age ( $21^{\text {th }}$ day of experiment) the body weight in control group $\mathrm{T}_{0}$ was recorded $1646.25 \pm 32.64 \mathrm{gm}$ and in the treated groups were $1710.34 \pm 46.36 \mathrm{gm}$ in group $\mathrm{T}_{1}$, $1670.64 \pm 43.01 \mathrm{gm}$ in group $\mathrm{T}_{2}$ and $1865.54 \pm 26.93 \mathrm{gm}$ in group $\mathrm{T}_{3}$. The average body weight of all treated groups were statistically significant $(\mathrm{p}<0.01)$ than the control group. The highest body weight was recorded in treated group $\mathrm{T}_{3}$ and lowest in control group $\mathrm{T}_{0}$.

On 35 days of age (28 $8^{\text {th }}$ day of experiment) the body weight in control group $\mathrm{T}_{0}$ was recorded $2120.74 \pm 46.37 \mathrm{gm}$ and in the treated groups were $2250.34 \pm 43.01 \mathrm{gm}$ in group $\mathrm{T}_{1}, 2140.64 \pm 35.36 \mathrm{gm}$ in group $\mathrm{T}_{2}$ and $2520.47 \pm 98.23 \mathrm{gm}$ in group $\mathrm{T}_{3}$. The highest body weight was recorded in group $\mathrm{T}_{3}$

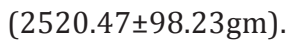

\begin{tabular}{|c|c|c|c|c|c|c|}
\hline \multirow{2}{*}{ Group } & \multirow{2}{*}{ No of Birds } & \multicolumn{5}{|c|}{ Body Weight Gain (gm) } \\
\hline & & 0 day & $7^{\text {th }}$ day & $14^{\text {th }}$ day & $21^{\text {st }}$ day & $28^{\text {th }}$ day \\
\hline $\mathrm{T}_{0}$ & 50 & $125.24 \pm 2.04$ & $530.56 \pm 3.54^{\mathrm{d}}$ & $901.24 \pm 13.45^{\mathrm{d}}$ & $1646.25 \pm 32.64^{\mathrm{d}}$ & $2120.74 \pm 46.37^{\mathrm{d}}$ \\
\hline $\mathrm{T}_{1}$ & 50 & $128.32 \pm 2.55$ & $550.43 \pm 7.91^{\mathrm{b}}$ & $955.54 \pm 16.58^{\mathrm{b}}$ & $1710.34 \pm 43.01^{\mathrm{b}}$ & $2250.34 \pm 35.36^{b}$ \\
\hline $\mathrm{T}_{2}$ & 50 & $130.35 \pm 3.53$ & $535.34 \pm 5.00^{c}$ & $949.37 \pm 8.43^{c}$ & $1670.64 \pm 46.36^{c}$ & $2140.64 \pm 43.01^{\mathrm{c}}$ \\
\hline $\mathrm{T}_{3}$ & 50 & $132.25 \pm 3.39$ & $563.21 \pm 8.60^{\mathrm{a}}$ & $1059,65 \pm 22.49^{\mathrm{a}}$ & $1865.54 \pm 26.93^{\mathrm{a}}$ & $2520.47 \pm 98.23^{\mathrm{a}}$ \\
\hline
\end{tabular}

*Values followed by different superscript in the same column differ significantly $p<0.01$. 
Body weight recorded on 14, 21, 28 and 35 days of age shows increased body weight and Increase body weight was gradual in group $\mathrm{T}_{0}$ but increase in other groups was rapid in comparison to control group. Total Erythrocyte count is presented in Table 1. On the final day of experiment (35 days of age) the values of TEC in control group $\mathrm{T}_{0}$ was $2.71 \pm 0.04$ million $/ \mathrm{mm}^{3}$ and in the treated group $\mathrm{T}_{1}$ was $3.00 \pm 0.02$ million $/ \mathrm{mm}^{3}$, Group $\mathrm{T}_{2}$ was $3.26 \pm 0.20 \mathrm{million} / \mathrm{mm}^{3}$ and group $\mathrm{T}_{3}$ was $3.29 \pm 0.21 \mathrm{million} / \mathrm{mm}^{3}$. The highest values of TEC was in the group $\mathrm{T}_{3}(3.29 \pm 0.21 \mathrm{million} /$ $\left.\mathrm{mm}^{3}\right)$ and lowest in control group $\mathrm{T}_{0}\left(2.71 \pm 0.04\right.$ million $\left./ \mathrm{mm}^{3}\right)$. All the values of treated groups were significantly higher than the control group $\mathrm{T}_{0}$.

Table 2: Effect of vitamins and enzymes on hematology of broilers.

\begin{tabular}{|c|c|c|c|c|c|}
\hline Group & No of Birds & TEC (millions $/ \mathrm{mm}^{3}$ ) & $\mathrm{Hb}(\mathrm{gm} / \mathrm{dl})$ & PCV (\%) & ESR \\
\hline T0 & 50 & $2.71 \pm 0.04^{c}$ & $7.64 \pm 0.15^{c}$ & $27.99 \pm 0.18^{c}$ & $2.40 \pm 0.12^{\mathrm{a}}$ \\
\hline $\mathrm{T} 1$ & 50 & $3.00 \pm 0.02^{\mathrm{ab}}$ & $8.38 \pm 0.14^{b}$ & $30.24 \pm 0.31^{b}$ & $2.00 \pm 0.29^{b}$ \\
\hline $\mathrm{T} 2$ & 50 & $3.26 \pm 0.20^{\mathrm{a}}$ & $8.70 \pm 0.21^{b}$ & $30.80 \pm 0.21^{\mathrm{b}}$ & $1.98 \pm 0.16^{b}$ \\
\hline T3 & 50 & $3.29 \pm 0.21^{\mathrm{a}}$ & $9.08 \pm 0.40^{\mathrm{a}}$ & $31.08 \pm 0.35^{\mathrm{a}}$ & $1.50 \pm 0.16^{c}$ \\
\hline
\end{tabular}

*Values followed by different superscript in the same column differ significantly $p<0.01$

Hemoglobin content in different groups of bird is presented in Table 2. On the final day of experiment (35 days of age) the values of $\mathrm{Hb}$ content in control group $\mathrm{T}_{0}$ was $7.64 \pm 0.15 \mathrm{gm} /$ $\mathrm{dl}$ and the treated group $\mathrm{T}_{1}$ was $8.38 \pm 0.14 \mathrm{gm} / \mathrm{dl}$, group $\mathrm{T}_{2}$ was $8.70 \pm 0.21 \mathrm{gm} / \mathrm{dl}$ and group $\mathrm{T}_{3}$ was $9.08 \pm 0.40 \mathrm{gm} / \mathrm{dl}$. The highest value of $\mathrm{Hb}$ content was recorded in group $\mathrm{T}_{3}(9.08 \pm 0.40 \mathrm{gm} /$ dl) and lowest value of $\mathrm{Hb}$ content was recorded in group $\mathrm{T}_{0}$ $(7.64 \pm 0.15 \mathrm{gm} / \mathrm{dl})$. All the values of packed cell volume (PCV) is presented in Table 2. On the final day of experiment PCV value of groups $\mathrm{T}_{0}, \mathrm{~T}_{1}, \mathrm{~T}_{2}$ and $\mathrm{T}_{3}$ were $27.99 \pm 0.18 \%, 30.24 \pm 0.31 \%$, $30.80 \pm 0.21 \%$ and $31.08 \pm 0.35 \%$ respectively. The highest value was recorded in group $\mathrm{T}_{3}(31.08 \pm 0.35 \%)$ and lowest value was recorded in group $\mathrm{T}_{0}(27.99 \pm 0.18 \%)$. All the values of treated groups were significantly higher than the control group $\mathrm{T}_{0}$.

Erythrocyte sedimentation rate (ESR) is presented in table 2. On the final day of experiment ESR value of groups $T_{0}, T_{1}, T_{2}$ and $\mathrm{T}_{3}$ were $2.40 \pm 0.12,2.00 \pm 0.29,1.98 \pm 0.16$ and $1.50 \pm 0.16 \mathrm{~mm}$ in $1^{\text {st }}$ hour respectively. The lowest value was found in group $\mathrm{T}_{3}$ $\left(1.50 \pm 0.16 \mathrm{~mm}\right.$ in first hour) and highest was in control group $\mathrm{T}_{0}$ $(2.40 \pm 0.12 \mathrm{~mm}$ in first hour). All the value of treated groups were significantly $(\mathrm{p}<0.01)$ decreased than the control group $\mathrm{T}_{0}$.

\section{Discussion}

The increased rate of body weight gain in the treated groups might be due to an increased feed intake, feed consumption, utilization, digestion, absorption and metabolism of supplied feed nutrient specially protein essential for their health and body weight gain. Increased live weight for addition of enzymes was similar to previous findings [11-15]. They concluded that improved feed utilization by exogenous enzyme is responsible for an increased live weight in broilers. This finding contradicts with the report of Preston. who found that enzyme inclusion did not improve performance. This work also deferred earlier report of who reported that live weight did not increase with enzyme supplementation in barley and triticale based diets.
The increased weight in present finding resembles Villar who reported that weight gain and feed efficiency increased statistically with vitamin supplementation. This present work is also in agreement with the earlier reports of Khatun, Gavrilona [16-18].

The increased level of total erythrocyte count, hemoglobin content and packed cell volume might be due to the initiative effects on hemopoietic organs. There are some vitamins such as vitamin $B_{12}$, pantothenic acid, folic acid and biotin which are essential for normal growth of the hemopoietic organs and erythropoiesis. The concentration of erythrocytes may be influenced by certain vitamins and drugs. The hematological parameters of present finding resembles to that of Dukes [19] who reported that the number of erythrocytes and other components of blood varied due to the influence of age, sex, environment, exercise, nutritional status and climate.

But the result of hematological parameters are contrary to Cengiz [20], who observed that there were not any significant effects on blood parameters (RBC, HB, PCV and TLC) after given vitamin. In group $\mathrm{T}_{1}$ and $\mathrm{T}_{2}$ multivitamins and enzymes were used respectively and the results of these two groups are in agreement with previous different studies. But in group $\mathrm{T}_{3}$ multivitamins and enzymes together were used and better results than that of group $\mathrm{T}_{1}$ and $\mathrm{T}_{2}$ were found [21-26].

\section{Acknowledgement}

This work was funded by The Ministry of Science and Technology, Government of Bangladesh through their fellowship scheme.

\section{References}

1. Huque QME (1999) Poultry production research programmes, nutrition, feeding and management programmes. Nutritional status of native poultry under scavenging. A Hand Book on Research Achievements and Activities, Bangladesh livestock Research Institute, Savar, Dhaka, Bangladesh. 
2. Huque KS, Sarker MSK, Huque QME, Islam MN (2001) Duck production in the Sylhet basin of Bangladesh prospects and problems. Proceedings of WPSA. $2^{\text {nd }}$ International Poultry Show and Seminar 16(17): 40-51.

3. Jaroni D, Scheideler SE, Beck M, Wyatt C (1999) The effect of dietary wheat middlings and enzyme supplementation. 1. Late egg production efficiency, egg yields, and egg composition in two strains of Leghorn hens. Poult Sci 78: 841-847.

4. Kidd MT, Morgan GW, Zumwalt CD (2001) Galactosidase enzyme supplementation to corn and soybean meal broiler diets J appl Poult Res 10: 186-193.

5. Graham KK, Kerley MS, Firman JD, Allee GL (2002) The effect of enzyme treatment of soybean meal on oligosaccharide disappearance and chick growth performance. Poult Sci 81: 1014-1019.

6. Giraldo LA, Tejido ML, Ranilla MJ, Ramos S, Carro MD (2008) Influence of direct-fed fibrolytic enzymes on diet digestibility and ruminal activity in sheep fed grass hay-based diet. J Anim Sci 86: 1617-1623.

7. Balamurugan R, Chandrasekaran D (2009) Effect of multi enzyme supplementation on weight gain, feed intake, feed efficiency and blood glucose in broiler chickens. Indian J Sci Technol 3: 193-195.

8. Bedford MR (2000) Exogenous enzymes in monogastric nutritiontheir current value and future benefits. Anim Feed Sci Technol 86: 1-13.

9. Acamovic T (2001) Commercial application of enzyme technology for poultry production. World Poult Sci J 57: 225-243.

10. Barrett AJ, Rawlings ND, Woessner JF (2003) The handbook of proteolytic enzymes ( $2^{\text {nd }}$ edn.), Academic Press.

11. Meng X, Slominski BA, Nyachoti CM, Campbell LD, Guenter W (2005) Degradation of cell wall polysaccharides by combinations of carbohydrase enzymes and their effect on nutrient utillization and broiler chicken performance. Poult Sci 84(1): 37-47.

12. Samarasinghe K, Messikommer R, Wenk C (2000) Activity of supplemental enzymes and their effect on nutrient utilization and growth performance of growing chickens as affected by pelleting temperature. Arch Tierernahr 53(I): 45-58.

13. Saleh F, Tahir M, Ohtsuka A, Hayashi K (2005) A mixture of pure cellulase, hemicellulase and pectinase improves broiler performance. Br Poult Sci 46(5): 602-606.

14. Silva SS, Smithard RR (2002) Effect of enzyme supplementation of a ryebased diet on xylanase activity in the small intestine of broilers and on nutrient disgestibility and growth performance of the birds. $\mathrm{Br}$ Poult Sci 43(2): 274-282.
15. Biswas T, Mandal L, Sarker SK (1999) Studies of enzymes supplementation and herbal preparation at different levels of energy on the performance of broilers. J Interac 3(1): 53-58.

16. Katun A (1982) Study the effect of the using different types of vitamins on the performance of broiler chicks. M.Sc. thesis, Department of Poultry Science, BAU, Mymensingh.

17. Gavrilona OA, Koturanov PN, Kadamanova LD, Maslovsul KS, Tatarinov NA (1989) Effect of vitamin on productivity of farm animals and birds Poult Abs 15(12): 340.

18. Christmas RB, Hars RH, Sloan DR (1995) The Absence of Vitamins and trace mineral and broiler performance. J Appl Poult Res 4(4): 407-410.

19. Dukes HH (1995) The Physiology of Domestic Animals, ( $7^{\text {th }}$ edn), Bailers Tindal and Co. London Poult Sci 47: 245-247.

20. Cengiz E, Tumen A, Yakar N (1993) Result of blood analysis of broiler fed different level of vitamin mixture. Fark Miktarlardavitaminiilebeslenenpiliclerdeazikananalizleri, Veteriner Fakultesi Dergisi Uludag Universitesi 12(3): 49-53.

21. Bangladesh Bauru of Statistics (2009) Year Book of Agricultural Statistics of Bangladesh. Bangladesh Bureau of Statistics. Ministry of Planning, Government of People's Republic of Bangladesh.

22. Irish GG, Barbour GW, Classen HL, Tyler RT, Bedford MR (1995) Removal of the galactosides of source from soybean meal using either ethanol extraction or exogenous galactosides and broiler performance. Poult Sci 74: 1484-1494.

23. Preston CM, Mc Kracken KJ, Mc Allister A (2000) Effect of diet form and enzyme supplementation on growth, efficiency and energy utilisation of wheat-based diets for broilers.Br Poult Sci 41(3): 324-331.

24. Veldman A, Vahl HA (1994) Xylanase in broiler diets with differences in characteristics and content of wheat. Br Poult Sci 35: 537-550.

25. Villar PG, Diaz CA, Guinzberg GE, Pablos JL, Pina E (2002) Effect of dietary supplementation with vitamin $\mathrm{C}$ or Vitamin $\mathrm{E}$ growth performance in broilers at risk of developing ascites syndrome. Am J Vet Res 63(5): 673-686.

26. Wu G, Bryant MM, Voitle RA, Roland SRDA (2005) Effect of $\beta$-mannanase in corn-soy diets on commercial Leghorns in second cycle hens. Poult Sci 84: 894-897. 
(C) This work is licensed under Creative

(C) DOI: 10.19080/JDVS.2018.05.555674

\section{Your next submission with Juniper Publishers} will reach you the below assets

- Quality Editorial service

- Swift Peer Review

- Reprints availability

- E-prints Service

- Manuscript Podcast for convenient understanding

- Global attainment for your research

- Manuscript accessibility in different formats ( Pdf, E-pub, Full Text, Audio)

- Unceasing customer service

Track the below URL for one-step submission https://juniperpublishers.com/online-submission.php 